\title{
BIOMECHANICAL MODELING OF THE PHYSICAL TRAINING OF GIRLS DURING AEROBIC ACTIVITIES IN NON-SCHOOL EDUCATIONAL INSTITUTIONS
}

\author{
Supilo I.P
}

Chernihiv National Pedagogical University

\begin{abstract}
Annotation. Purpose: to validate the effectiveness of biomechanical modeling of physical training of girls. Material: the study involved 90 girls aged 16-18 years (60 girls and recreation groups and 30 - sporting group aerobics). Results: during the study of quantitative biomechanical characteristics of the physical training of girls was identified the quantitative biodynamic and coordination structure of motor characteristics during aerobics. When comparing girls identified the best girls sports group thus constructed biomechanical model. For the considered model biodynamic structure includes the following indicators: GRAD; Fz max; Tmax; F max; Tsum; G; Tps. To the graphic model of the coordination patterns included the following indicators: EllS; $\mathrm{MO}(\mathrm{x}) ; \mathrm{LY} \mathrm{mm}$; Lx mm; JEF \%;V mm/s; IV; R mm. Conclusions: obtain the quantitative biomechanical model of indicators of physical training of girls, which is the basis for objective justification and development of a technique of aerobics, and to use these biomechanical models as a control and the future of forecasting.
\end{abstract}

Keywords: biomechanics, aerobics, achievement, motive, preparedness, girls.

\section{Introduction}

Control over girls' health strengthening and preservation, formation of their demand in motion functioning and healthy life style are one of main tasks of the present time.

Modern life style of school age girls is in contradiction with their organism's physiological demands and deficit of motion activity results in increasing of morbidity and weakening of their learning potential. Computerization and rather difficult educational programs intensify educational process and sharply restrict motion functioning. Alongside with deficit of motion functioning we observe reduction of girls' motion fitness.

Nowadays there happens active implementation of innovative methodic in order to achieve and maintain human optimal status in compliance with person's motivation and individual features (M.M. Bulatova [3], V.B. Zinchenko [6], Yu.A. Usachov [9]). Analysis of scientific-methodic literature witnesses that at present all forms of health related physical education are pointed at solution of first priority problem: formation, development and strengthening of health exactly with the newest means of physical education and sports.

Analysis of health related activity problems witnesses that one of the most popular kinds of health related physical education is aerobic, owing to its accessibility, emotionality and effectiveness. Just at aerobic trainings positive emotional background is created, level of motion fitness rises as well as interest to physical exercises' practicing.

But, as on to day in practice of health related aerobics there are no objective methodic of measurement and quantitative evaluation of girls' motion fitness that is an obstacle to working out and correction of aerobic trainings.

Exactly method of simulation in pedagogic researches is a mean of information's ordering and permits to deeper and more completely study the essence of researched phenomenon [2]. The problems of simulation in pedagogic activity were regarded in works by S.I. Arkhangelskiy [1], A.N. Dakhin [5], N.V. Kuzmina [7] et al.

Construction of comprehensive model permits to receive new information about object's behavior, to reveal interconnections and regularities, which can not be found with other methods of analysis [11]. Exactly simulation makes possible to briefly render required information. Simulation has its own nature and functions and is a mean of systemic approach, in the basis of which there is researching of objects as systems; the value of this method is that it permits to naturally combine quantitative and qualitative analysis [4].

In physical education simulation is one of modern and promising branches of educational process's improvement, which permits for us to create a structure of indicators of girls' motion fitness.

The progress of modern bio-mechanical methodology opens certain prospects for further perfection of training's means and methods [7, 12-15]. Development of technologies and methods of measurement, application of computer systems in researches significantly widen potentials of physical exercises in this direction. That is why it is of certain interest to work out aerobic trainings, considering bio-mechanical characteristics of girls' motion fitness.

The work has been fulfilled in compliance with priority direction of scientific researches of Chernigov pedagogic university, named after T.G. Shevchenko "Didactic foundations of formation of motion functions of physical education and sports' trainees" (state registration number 0108U000854 dt. 19.12.2008) and in compliance with university's topic "Pedagogic ways to formation of healthy life style of different age school children" (state registration number 0112U001072 dt. 18.01.2012).

Purpose, tasks of the work, material and methods

The purpose of the work is to ground effectiveness of application of girls' motion fitness's bio-mechanical simulation at aerobic training in out-of-school educational instit6utions.

For solution of this task we used method of theoretical analysis and generalization of literature sources, devoted to this problem; simulation, stabilography, strain dynamometry, mathematical statistics. 
In our research 90 girls of 16-18 years old age participated (60 of them practiced health related aerobic and 30 - sport aerobic).

The researches were conducted on the base of training center of vocational-6ecnical education in Chernigov region (Regional public organization "Federation of aerobics of Chernigovschina" and in Chernigov national pedagogic university, named after T.G. Shevchenko.

\section{Results of the research}

As a result of complex examination of girls, who train aerobic in health related and sport groups in out-ofschool educational establishments of Chernigov we received great quantity of indicators of their motion fitness, which required ordering. It forced us to apply method of simulation and models' construction.

Thus, correlation analysis resulted in determination of the most informatively significant indicators, which had the greatest quantity of interconnections and, consequently, significantly influenced on girls' motion fitness. With the help of simulation method, on the base of received data we constructed graphic-analytical models for realization of quantitative and qualitative control of girls' motion fitness at aerobic trainings in out-of-school educational institutions.

On the base of the most informative bio-mechanical indicators, received with strain dynamometry method, we built graphic-analytical model of bio-dynamic structure of high jump from the spot (see fig.1): the most informative indicators of strength's gradient (GRAD), which was $9.34 \%$; the second by informative meaning indicators of maximal push off force in respect to vertical axis (Fz max) was 8.38\%; the third was impulse of force (I) - 7.62\%; The forth was indicator of maximal time of action's fulfillment (Tmax) $-7.54 \%$; the fifth was maximal meaning of support resistance responses' components (F $\max )-7.5 \%$; the sixth by importance was total time of action's fulfillment (Tsum), which was $7.41 \%$; the seventh - indicator of body weight (P) -7.19\%; the eights was indicators of time of half squatting (Tps) $-7.01 \%$.

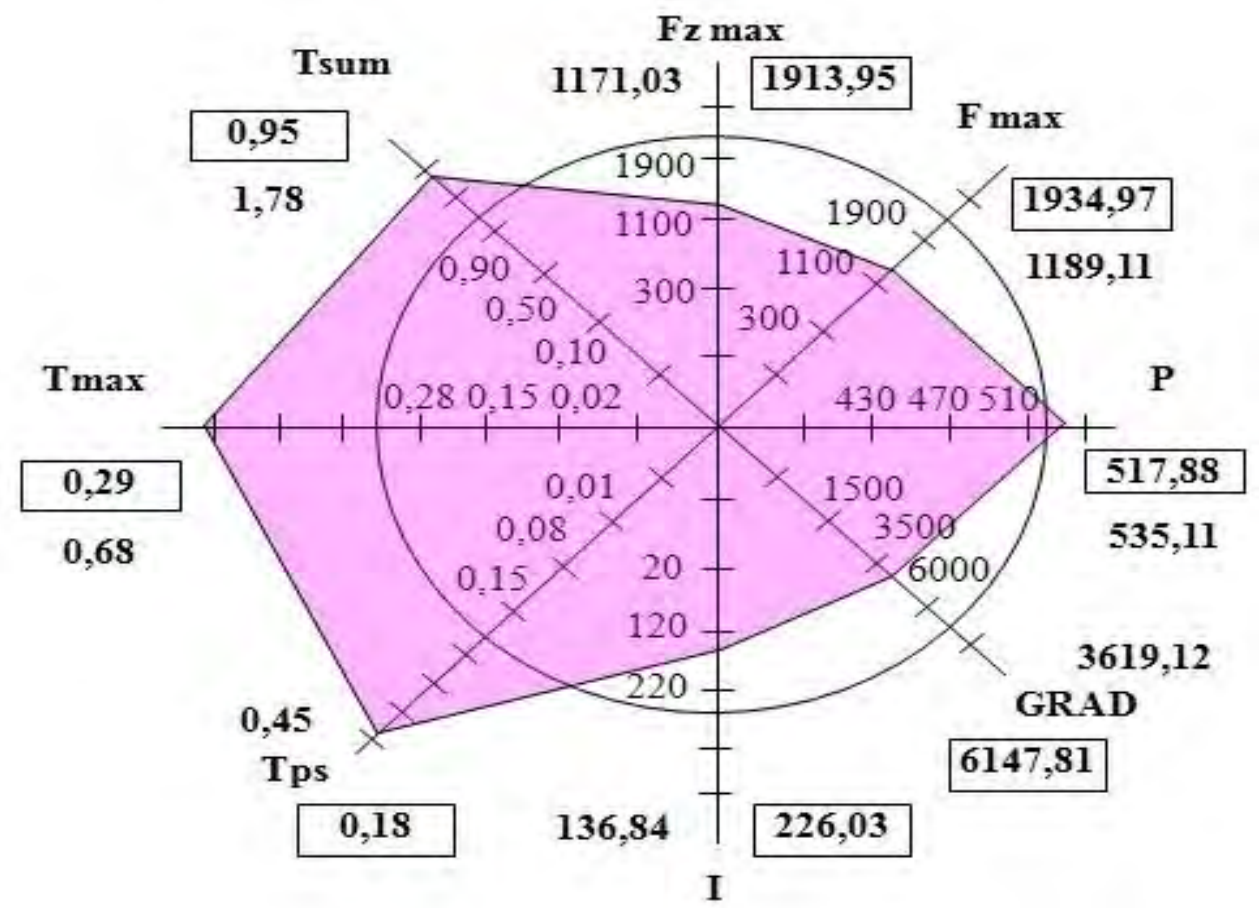

Fig.1. Graphic-analytical model of bio-dynamic structure of high jump from the spot, fulfilled by girls.

As a result of stabilography method's application [9] we received indicators, which composed graphicanalytical model of coordination structure (see fig.2).

Thus, the most significant in girls' coordination fitness was indicator of ellipse's area (EllS), which was 9.02\%; the second by significance was indicator of mean displacement in respect to frontal axis (MO (x)), which was 7.91\%; the third by quantity of connections was indicator of trajectory length in respect to sagittal axis (LY) - 7.82\%; the forth place was taken by indicator of trajectory length in respect to frontal axis $(\mathrm{Lx})-7.81 \%$; the fifth was indicator of balance function (ЯФР) -7.16\%; the sixth was indicator of mean velocity of GMC travelling (V) - 7.08\%, the seventh place was taken by indicator of velocity(IV) $-6.98 \%$ and the eighth place - indicator of mean scattering (mean radius) of $\mathrm{MC}(\mathrm{R})$ deviation $-6.86 \%$. 


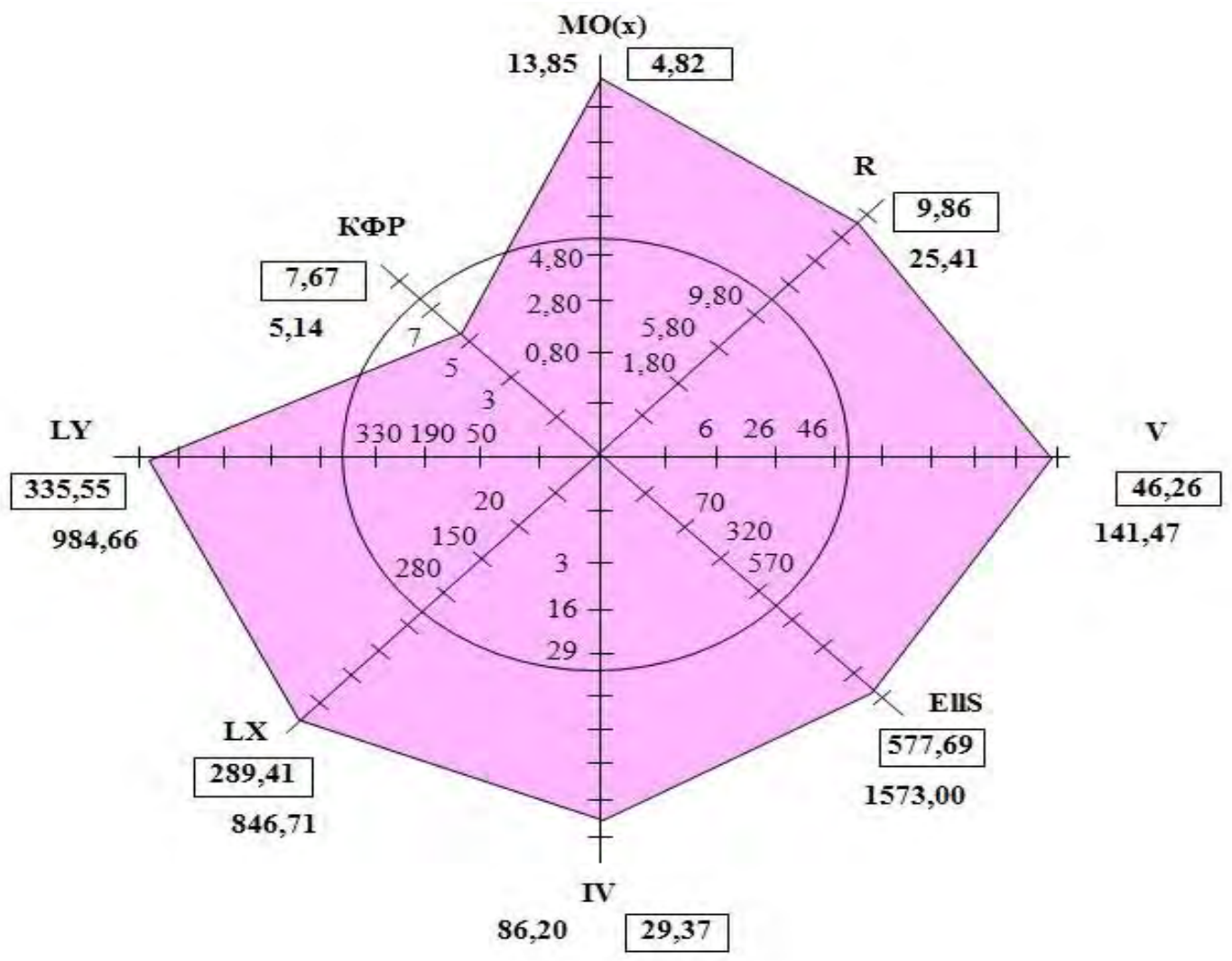

Fig.2. Graphic-analytical model of girls' coordination structure

\section{Conclusions:}

Thus, the received data permit to provide basis for selection of means for aerobic trainings on the base of prognostic bio-mechanical models. Besides, bio-mechanical monitoring makes it possible to correct girls' motion fitness, to provide control over aerobic trainings and to make further prognosis.

\section{References:}

1. Arkhangel'skij S.I. Uchebnyj process $v$ vysshej shkole, ego zakonomernye osnovy $i$ metody [The educational process in higher education, its legitimate principles and methods], Moscow, Pedagogy, 1989, 368 p.

2. Babans'kij E.B., Gurfinkel' V.S., Romel' E.L. Fiziologicheskij zhurnal SSSR [Physiological journal of the USSR], 1955, vol.12(3), pp. 423-426.

3. Bulatova M.M. Teoriia i metodika fizichnogo vikhovannia i sportu [Theory and methods of physical education and sport], 2007, vol.1, pp. 3-7.

4. Gamalij V.V. Biomekhanicheskie aspekty tekhniki dvigatel'nykh dejstvij v sporte [Biomechanical aspects of the art of motor actions in sport], Kiev, Scientific World,, 2007, 211 p.

5. Dakhin A.N. Standarty $i$ monitoring v obrazovanii [Standards and monitoring in education], 2004, vol.4, pp. 4660.

6. Zinchenko V.B., Usachev Iu.A. Fitnes-tekhnologii $v$ fizicheskom vospitanii [Fitness technology in physical education], Kiev, NAU, 2011, 152 p.

7. Kuz'mina N.V. Formirovanie sposobnostej [Formation of abilities], Leningrad, 1979, 200 p.

8. Nosko M.O., Arkhipov A.A. Visnik Chernigivs'kogo derzhavnogo pedagogichnogo universitetu [Bulletin of the Chernihiv State Pedagogical University], 2013, vol.107(2), pp. 67-70.

9. Usachev V.I. Sposob kachestvennoj ocenki funkcii ravnovesiia. Patent na izobretenie 2175851 [A method for qualitative assessment of balance function. A patent for an invention 2175851], Moscow, 2001, $4 \mathrm{p}$.

10. Shestakov M.P. Ispol'zovanie stabilografii v sporte [Using stabilography in sport], Moscow, TVT Divisjon, 2007, $112 \mathrm{p}$.

11. Shennon R. Imitacionnoe modelirovanie sistem [Simulation modeling systems], Moscow, World, 1978,402 p.

12. Adashevskiy V.M., Iermakov S.S., Logvinenko Y.I., Cieślicka Mirosława, Stankiewicz Błażej, Pilewska Wiesława. Individual athletes' biomechanical features of interaction with objects in art gymnastics. Pedagogics, psychology, medical-biological problems of physical training and sports, 2014, vol.6, pp. 3-10. doi:10.6084/m9.figshare.1004089

13. Adashevskiy V.M., Iermakov S.S., Firsova Iu.Iu. Physical mathematical modelling of difficult elements of acrobatic rock-and-roll. Physical Education of Students, 2013, vol.3, pp. 3-10. doi:10.6084/m9.figshare.662463 
14. Prusik Krzysztof, Prusik Katarzyna, Kozina Zh.L., Iermakov S.S. Features of physical development, physical preparedness and functional state of boys and girls - students of Polish higher educational establishments. Physical Education of Students, 2013, vol.1, pp. 54-61. doi:10.6084/m9.figshare.96415

15. Żukowska Hanna, Szark-Eckardt Mirosława, Muszkieta Radosław, Iermakova T.S. Characteristics of body posture in the sagittal plane and fitness of first-form pupils from rural areas. Pedagogics, psychology, medical-biological problems of physical training and sports, 2014, vol.7, pp. 50-60. doi:10.6084/m9.figshare.1015583

Information about the author:

Supilo I.P.: ORCID: http://orcid.org/0000-0003-0911-0460; sle02@ yandex.ru; Chernihiv National Pedagogical University; Str. Polubotko Getman, 53, Chernigov, 14013, Ukraine.

Cite this article as: Supilo I.P. Biomechanical modeling of the physical training of girls during aerobic activities in non-school educational institutions. Physical education of students, 2014, vol.6, pp. 73-76. doi:10.15561/20755279.2014.0614

The electronic version of this article is the complete one and can be found online at: http://www.sportpedu.org.ua/html/arhive-e.html

This is an Open Access article distributed under the terms of the Creative Commons Attribution License, which permits unrestricted use, distribution, and reproduction in any medium, provided the original work is properly cited (http:// creativecommons.org/licenses/by/3.0/deed.en).

Received: 10.06 .2014

Published: 30.06 .2014 